\title{
The Historic Role of Crocodiles and Other African Aquatic Pests in Current Sport Championships
}

\author{
Simcha Lev-Yadun \\ Department of Biology \& Environment, Faculty of Natural Sciences, University of Haifa-Oranim, Tivon, Israel \\ Email: levyadun@research.haifa.ac.il
}

Received 1 October 2014; accepted 29 March 2015; published 3 April 2015

Copyright (C) 2015 by author and Scientific Research Publishing Inc.

This work is licensed under the Creative Commons Attribution International License (CC BY). http://creativecommons.org/licenses/by/4.0/

(c) (i) Open Access

\begin{abstract}
Top achievements in modern sports are not distributed evenly among humans of various origins. Athletes of African origin dominate several fields of athletics, especially short- and long-distance running, which differ in their physiological and muscle structure characters and requirements. This contrasts dramatically with their near absence from the group of leading swimmers at all distances. The conspicuous absence of world-class swimmers of African origin cannot be explained by current or recent social aspects or by the history of their discrimination, and therefore deserves an alternative explanation. I propose that the conspicuous weakness of athletes of African origin in swimming is related to their evolution in the natural African environment with the probable inherited and a certain biological and/or cultural fear of predation by crocodiles and of infection by various pathogens and parasites. Members of the genus Homo that emigrated from Africa during the last 1.8 million years or have evolved outside Africa had sufficient time to get rid of the biological and/or cultural fear of swimming directly, or by gene exchange with contemporary groups that left Africa long ago and had adapted to safer water habitats. The release from the fear of crocodiles, pathogens and parasites at higher latitudes must have influenced other aspects of environmental exploitation of aquatic habitats by various hominin types, an issue outside the scope of his assay.
\end{abstract}

\section{Keywords}

African Origin, Crocodiles, Human Evolution, Predation, Running, Swimming

Top achievements in modern sports are not distributed evenly among nations or people of various origins, as demonstrated in the 2013 summer world championships in swimming (held in Spain) and athletics (held in the Russian Federation). The dominance of athletes of African origin in several fields of athletics, especially both 
short and long distance running, two running types that require different physiological and muscle structure characters (e.g., Epstein, 2013), contrasts dramatically with their near absence from the group of leading swimmers at all distances.

Since the 1960's, when the general discrimination against people of African origin, including in sports, began to relax, their inherent superiority in certain types of sports, especially running, became obvious. Therefore, the conspicuous absence of world-class swimmers of African origin, which cannot be related to current or recent social phenomena, or to the availability of adequate swimming pools for training, deserves an alternative explanation. Moreover, concerning both air and water temperature, and the human body energy budget, it is much easier to swim in hot countries than in cold ones as swimming in cold water may be even deadly as a result of severe energy loss (Tipton et al., 1999; Brannigan et al., 2009). I propose that the conspicuous weakness of athletes of African origin in swimming is related to their biological and cultural evolution with the very risky African natural aquatic environment.

Archaeological and molecular studies show that during at least the last 1.8 million years, hominines (Lordkipanidze et al., 2013) and later humans (e.g., Stewart \& Stringer, 2012), emigrated out of Africa again and again, sometimes mixing with other human types such as the Neanderthals, the Denisovans and at least one other, earlier unknown archaic human group. All these are human groups that had left Africa tens, hundreds of thousands or even millions of years earlier (Stewart \& Stringer, 2012; Cann, 2013; Lachance \& Tishkoff, 2013). The molecular evidence for probable earlier events of genetic mixings among various hominines that lived outside Africa was likely lost with their degraded DNA in very early skeleton finds. However, it should be considered that stone tool production traditions indicate an African origin of various hominin groups that left Africa 1.3 0.75 million years ago (Bar-Yosef \& Goren-Inbar, 1993; Goren-Inbar et al., 2000), hominin groups for which we have no DNA evidence. Thus, the modern Homo sapiens populations that were separated from those currently found in Africa some 160,000 years ago (e.g., Klyosov, 2014) had sufficient time to develop local adaptations to Eurasian conditions based on their own gene pool or by supplementation by some genetic contributions from various other Eurasian-adapted ancient local Homo spp. populations (e.g., Stewart \& Stringer, 2012; Huerta-Sánchez et al., 2014). However, understanding the relative roles of Africa and Eurasia in human evolution is still far from complete (e.g., Klyosov, 2014).

Concerning the evolutionary adaptations for swimming, there was a dramatic difference between African and Eurasian temperate regions, for instance, the existence versus the lack of crocodiles and of the less important Hippopotamus amphibius (Dunham et al., 2010). Of additional great important may be the various other common African aquatic pests such as Schistosomiasis, also known as bilharzia (Jordan \& Rosenfield, 1983), Dracunculiasis (Guinea worm disease) (Cairncross et al., 2002), and Elephantiasis and Loa (river blindness) (Cox, 2002) to mention just the famous ones. In the Old World, crocodiles are not found in latitudes higher than $35^{\circ}$ (Martin, 2008) and there are no other common freshwater predators as dangerous to humans as crocodiles in latitudes higher than $35^{\circ}$. Crocodiles are much more dangerous to swimmers than hippopotami not only because of the current larger numbers of crocodile casualties (e.g., Dunham et al., 2010) even after they were hunted in many places to the verge of extinction (Musambachime, 1987), but because crocodiles, which specialize in ambush hunting, attack by surprise, and hippopotami, which as vegetarians attack for other reasons are larger and are much easier to spot and avoid. For millions of years, African mammals the size of humans and even those that are several times larger, were exposed to a critical risk of predation by crocodiles whenever they approached aquatic habitats. Their only available defensive strategy was to lower the risk by avoiding aquatic habitats as much as possible. This avoidance character should have been selected for strongly and repeatedly. The same is true concerning the above-mentioned pests and parasites as well as others that were not mentioned. Therefore, for at least hundreds of thousands of years (e.g., Stewart \& Stringer, 2012; Cann, 2013; Lachance \& Tishkoff, 2013) and probably for almost 1.8 million years, early hominine types and $H$. sapiens living outside Africa or outside other tropical or hot regions, especially in Europe and in non-tropical or subtropical Asia, could develop their swimming abilities directly and possibly also acquire some additional adaptations by gene or even cultural exchange with other Homo spp. types that had left Africa and its dangerous waters much earlier and evolved accordingly. If the fear of aquatic habitats has a genetic component, what I propose here is a classic case of vestigialization, loss of non-functional characters sensu Fong et al. (1995).

In Africa (and other crocodile, pathogen, and parasite-rich hot regions such as south East Asia), hominines and humans that had a strong tendency to spend much time in rivers and lakes were repeatedly exposed to a strong predation pressure by crocodiles and various parasites and pathogens and selected against. It should be 
remembered that before the development of large and safe boats or rafts, and when crocodiles were much more abundant than today because they had not yet been hunted as in recent millennia and especially in the last century (Musambachime, 1987), their mortal danger must have caused a strong biological/cultural imprint in humans living where they were abundant (e.g., Pooley et al., 1989; McGregor, 2005). This, combined with the many other common dangers of African aquatic habitats mentioned above, seem to be the reason for the lower tendency of people of African origin for water-related sports.

Fear from predation based on deep genetic foundations seems to have influenced human behavior. Some of our fears belong to very early Mesozoic (mammalian-wide) 140-million-year old neural circuits, other but still very early fears are Cenozoic (20 million years old), and others (Homo specific), are of Mid- and Upper Paleolithic origin (Bracha, 2006). Rhesus monkeys, for instance, fear toy crocodiles (Cook \& Mineka, 1989) and predation in general had a significant influence on primate evolution (Anderson, 1986). Thus, when it comes to the edge of the human athletic ability, like the current level of competitive sports happens to be, the contrasting abilities of athletes of African versus those of Euro-Asian origin concerning running and swimming seem to reflect the historical influence of the distribution of the most dangerous common aquatic predators-the crocodilians as well as the common occurrence of a multitude of pathogens and parasites in African waters. I propose that the long history of avoiding crocodile attacks and aquatic parasites, which is the very best defensive strategy, is at the root of the current weakness of athletes of African origin in sportive swimming.

Several recent successful attempts to understand the biological basis for some types of athletic superiority revealed a monogenic biochemical basis for such an advantage (Epstein, 2013), but not all adaptations are monogenic or even physiological from a biochemical point of view. There are current $H$. sapiens athletes of recent African origin that have biochemical adaptations for either sprinting or the endurance needed for long distance running, but such types of genetic adaptations for athletics that have been studied to date (e.g., Lachance \& Tishkoff, 2013; Epstein, 2013) may not provide the correct explanation when fear of predation and of aquatic habitats is involved. I propose that the dramatically lower tendency to swim by people of recent African origin is probably behavioral (with either a genetic or cultural basis) rather than physiological, and should therefore be studied via the recording of brain activity following the exposure to images of, or actual crocodiles, as was recently done to examine the differences in brain activity between women and men (Ingalhalikar et al., 2014).

\section{Acknowledgements}

I thank an anonymous reviewer for his critically helpful suggestions.

\section{References}

Anderson, C. M. (1986). Predation and Primate Evolution. Primates, 27, 15-39. http://dx.doi.org/10.1007/BF02382520

Bar-Yosef, O., \& Goren-Inbar, N. (1993). The Lithic Assemblage of 'Ubeidiya. Qedem 34. Institute of Archaeology, Hebrew University, Jerusalem.

Bracha, H. S. (2006). Human Brain Evolution and the "Neuroevolutionary Time-Depth Principle": Implications for the Reclassification of Fear-Circuitry-Related Traits in DSM-V and for Studying Resilience to Warzone-Related Posttraumatic Stress Disorder. Progress in Neuro-Psychopharmacology and Biological Psychology, 30, 827-853. http://dx.doi.org/10.1016/j.pnpbp.2006.01.008

Brannigan, D., Rogers, I. R., Jacobs, I., Montgomery, A., Williams, A., \& Khangure, N. (2009). Hypothermia Is a Significant Medical Risk of Mass Participation Long-Distance Open Water Swimming. Wildlife and Environmental Medicine, 20, 14-18. http://dx.doi.org/10.1580/08-WEME-OR-214.1

Cairncross, S., Muller, R., \& Zagaria, N. (2002). Dracunculiasis (Guinea Worm Disease) and the Eradication Initiative. Clinical Microbiology Reviews, 15, 223-246. http://dx.doi.org/10.1128/CMR.15.2.223-246.2002

Cann, R. C. (2013). Y Weigh in Again on Modern Humans. Science, 341, 465-467. http://dx.doi.org/10.1126/science.1242899

Cook, M., \& Mineka, S. (1989). Observational Conditioning of Fear to Fear-Relevant versus Fear-Irrelevant Stimuli in Rhesus Monkeys. Journal of Abnormal Psychology, 98, 448-459. http://dx.doi.org/10.1037/0021-843X.98.4.448

Cox, F. E. G. (2002). History of Human Parasitology. Clinical Microbiology Reviews, 15, 595-612. http://dx.doi.org/10.1128/CMR.15.4.595-612.2002

Dunham, K. M., Ghiurghi, A., Cumbi, R., \& Urbano, F. (2010). Human-Wildlife Conflict in Mozambique: A National Perspective, with Emphasis on Wildlife Attacks on Humans. Oryx, 44, 185-193.

http://dx.doi.org/10.1017/S003060530999086X 
Epstein, D. (2013). The Sports Gene. Inside the Science of Extraordinary Athletic Performance. New York: Current.

Fong, D. W., Kane, T. C., \& Culver, D. C. (1995). Vestigialization and Loss of Nonfunctional Characters. Annual Review of Ecology and Systematics, 26, 249-268. http://dx.doi.org/10.1146/annurev.es.26.110195.001341

Goren-Inbar, N., Feibel, C. S., Verosub, K. L., Melamed, Y., Kislev, M. E., Tchernov, E., \& Saragusti, I. (2000). Pleistocene Milestones on the Out-of-Africa Corridor at Gesher Benot Ya’aqov, Israel. Science, 289, 944-947. http://dx.doi.org/10.1126/science.289.5481.944

Huerta-Sánchez, E., Jin, X., Asan Bianba, Z., Peter, B. M., Vinckenbosch, N., Liang, Y., Yi, X. et al. (2014). Altitude Adaptation in Tibetans Caused by Introgression of Denisovan-Like DNA. Nature, 512, 194-197. http://dx.doi.org/10.1038/nature13408

Ingalhalikar, M., Smith, A., Parker, D., Satterthwaite, T. D., Elliott, M. A., Ruparel, K., Hakonarson, H. et al. (2014). Sex Differences in the Structural Connectome of the Human Brain. Proceedings of the National Academy of Sciences of the United States of America, 111, 823-828. http://dx.doi.org/10.1073/pnas.1316909110

Jordan, P., \& Rosenfield, P. L. (1983). Schistosomiasis Control: Past, Present, and Future. Annual Review of Public Health, 4, 311-334. http://dx.doi.org/10.1146/annurev.pu.04.050183.001523

Klyosov, A. A. (2014). Reconsideration of the "Out of Africa” Concept as Not Having Enough Proof. Advances in Anthropology, 4, 18-37. http://dx.doi.org/10.4236/aa.2014.41004

Lachance, J., \& Tishkoff, S. A. (2013). Population Genomics of Human Adaptation. Annual Review of Ecology, Evolution, and Systematics, 44, 123-143. http://dx.doi.org/10.1146/annurev-ecolsys-110512-135833

Lordkipanidze, D., de León, M. S. P., Margvelashvili, A., Rak, Y., Rightmire, G. P., Vekua, A., \& Zollikofer, C. P. E. (2013). A Complete Skull from Dmanisi, Georgia, and the Evolutionary Biology of Early Homo. Science, 342, 326-331. http://dx.doi.org/10.1126/science.1238484

Martin, S. (2008). Global Diversity of Crocodiles (Crocodilia, Reptilia) in Freshwater. Hydrobiology, 595, 587-591. http://dx.doi.org/10.1007/s10750-007-9030-4

McGregor, J. (2005). Crocodile Crimes: People versus Wildlife and the Politics of Postcolonial Conservation on Lake Kariba, Zimbabwe. Geoforum, 36, 353-369. http://dx.doi.org/10.1016/j.geoforum.2004.06.007

Pooley, A. C., Hines, T., \& Shield, J. (1989). Attacks on Humans. In C. A. Ross (Ed.), Crocodiles and Alligators (pp. 172-187). London: Merchant Press.

Musambachime, M. C. (1987). The Fate of the Nile Crocodile in African Waterways. African Affairs, 86, 197-207.

Stewart, J. R., \& Stringer, C. B. (2012). Human Evolution Out of Africa: The Role of Refugia and Climate Change. Science, 335, 1317-1321. http://dx.doi.org/10.1126/science.1215627

Tipton, M., Eglin, C., Gennser, M., \& Golden, F. (1999). Immersion Deaths and Deterioration in Swimming Performance in Cold Water. The Lancet, 354, 626-629. http://dx.doi.org/10.1016/S0140-6736(99)07273-6 